\title{
Artropoda yang Berasosiasi pada Ekosistem Tanaman Lada
}

\author{
I M. TRISAWA, I W. LABA, DAN W.R. ATMADJA \\ Balai Penelitian Tanaman Rempah dan Obat \\ Jl. Tentara Pelajar No. 3, Bogor \\ (diterima Mci 2004, disetujui . Igustus 2004)
}

\begin{abstract}
Association of Arthropod on Pepper Plant Ecosystem. Ecosystem management of pepper between cover crops, Araibis pintoil, cropping system with corn, soybean and, limited weeding. The objectives of this research was to find out biodiversity of arthropods on the pepper ccosystem. This experiment was conducted in Lampung since May to September 2002. They are divided 5 trearments they are pepper with $A$. pintoil, pepper with corn, pepper with soybean, pepper with limited weeding and control. The randomized blok design was used with 5 replications. The result indicated that on the pepper ecosystem was found 44 kind of arthropods. The status of arthropod are: fitofag $(47.73 \%)$, omnivorus $(6.82 \%)$, natural enemies $(34.09 \%)$ and pollination $(11.36 \%)$. Distribution of each species was various at each treatment, between 26-34 species. The lowest population was found on pepper with corn, while on the highest populations were occurred on the pepper with $A$. pintoüt and control. The insects population of Acrididae, Tetrigidae, Grylidae (Orthoptera), Blattidae, Drosophillidae and Farmicidae always higher than an other insect. In this research were found 10 ordo of arthropod. Hymenoptera (Formicidac) and Araneida are dominant of arthropod and distribured at all treatment. Arthropod at pepper plant was the most abundant at pepper plant with $A$. pintoin. In the pepper standing plant it were only found three order, they are Hymenoptera, Araneida and Hemiptera. Beside at pepper plant and pepper standing plant, some of arthropod was found associated with $A$. pintoit, corn, soybean and weed. Order of Orthoptera mainly greeshopper was dominating at all of plant.
\end{abstract}

KEY WORDS: Piper nigrum, pepper ecosystem, athropod.

\section{PENDAHULUAN}

Jumlah dan jenis filum artropoda paling besar dibandingkan filum lain dan tersebar pada berbagai ekosistem kehidupan. Hubungannya dengan ekosistem pertanian, artropoda memegang peranan sangat penting khususnya dari kelas insekta (scrangga) yang merupakan kelas terbesar dari filum tersebut. Chinery (1991) mengatakan bahwa sekitar satu juta jenis serangga telah diidentifikasi dan dinamai.

Ekosistem pertanian yang dinamis dan kurang stabil memberikan pengaruh terhadap struktur dan fungsi artropoda yang ada di dalamnya. Keadaan ekosistem pertanian yang lebih sederhana, menurut Sosromarsono (1981) dapat menyebabkan satu atau lebih organisme pemakan tumbuhan menjadi hama dari tanaman yang dibudidayakan. Perubah- 
an status dari bukan hama menjadi hama disebabkan karena berlimpahnya tanaman makanan. Untung dan Sudomo (1997) mengatakan akan terjadi dominasi suatu jenis organisme terhadap organisme lainnya yang disebabkan karena di dalam ekosistem banyak mekanisme alami yang bekerja secara efektif dan efisien. Kondisi ekologi yang ada berpengaruh terhadap kehadiran organisme.

Pada budidaya tanaman lada, pengelolaan ekosistem di dalamnya diarahkan terhadap keanekaragaman hayati artropoda. Pola ekosistem yang dibentuk diharapkan mampu menciptakan kondisi yang kurang menguntungkan terhadap perkembangan populasi serangga yang merugikan, tetapi sebaliknya menguntungkan untuk musuh alami. Populasi serangga yang merugikan diupayakan berada dalam keadaan keseimbangan di bawah ambang kerusakan. Menurut Sastrosiswojo dan Oka (1997) memperhatikan keanekaragaman hayati merupakan salah satu tujuan komprehensif dalam tujuan pengendalian hama terpadu (PH1).

Salah satu pola pengelolaan ekosistem yang dikembangkan pada tanaman lada adalah penanaman penutup tanah dari jenis kacang-kacangan, Arachis pintoii. Pola ini dimaksudkan untuk menciptakan ekologi yang menguntungkan bagi perkembangan musuh alami hama utama lada. Tanaman A. pintoii dapat meningkatkan parasitisasi parasitoid Spatbius piperis terhadap penggerek batang lada. Tingkat parasitisasi tanpa A. pintoii berkisar antara $5,2-10,8 \%$, sedangkan dengan $A$. pintoil $25-50 \%$ (Suprapto, 2000).

Penggunaan tanaman penutup tanah $A$. pintoii atau jenis tanaman lain yang bersifat tumpangsari dengan lada, diharapkan juga dapat memicu kehadiran serangga-serangga lain yang berpotensi sebagai musuh alami hama utama lada. Parasitoid telur hama buah lada, Ooenyrtus malayensis merupakan agen hayati yang potensinya cukup tinggi untuk dikembangkan.

Pemilihan jenis tanaman sela (tumpangsari) diantara tanaman lada, di samping untuk hasil tambahan petani juga untuk merangsang musuh alami atau serangga berguna lain datang. Penanamannya diupayakan tidak merusak atau mengganggu perakaran lada. Tindakan kulrur teknis seperti pemupukan dapat diserap sekaligus oleh kedua jenis tanaman baik oleh lada maupun tanaman sela. Tanaman jagung dan kedelai adalah 2 jenis tanaman yang dapat dijadikan alternatif sebagai tanaman sela. Pola tanam lada dengan jagung dan kedelai memberikan tambahan pendapatan petani sebesar Rp. 416.519 untuk luas kebun 0,75 ha di samping meningkatkan produksi lada (Dhalimi et al., 1996).

\section{BAHAN DAN METODE}

Penelitian dilaksanakan di kebun lada petani seluas $\pm 1,5$ ha di Lampung Utara. Umur tanaman lada berkisar antara 5-7 tahun, sudah berproduksi dan tidak pernah dilakukan pengendalian hama maupun penyakit. 
Penelitian menggunakan rancangan acak kelompok dengan 5 perlakuan dan masing-masing diulang 5 kali. Perlakuan terdiri dari (a) pertanaman lada dengan penutup tanah $A$. pintoii, (b) tanaman lada dengan tumpangsari jagung, (c) tanaman lada dengan tumpangsari kedelai, (d) tanaman lada dengan penyiangan terbatas, dan (e) kontrol, tanpa penyiangan, tanpa tumpangsari, dan tanpa penutup tanah A. pintoii.

I.uas petak setiap ulangan $\pm 500 \mathrm{~m}^{2}$ yang berisi \pm 150 tanaman lada. Total tanaman lada untuk setiap perlakuan \pm 750 tanaman, diluar tanaman pembatas (border). Jarak antar perlakuan $\pm 500 \mathrm{~m}$. Tanaman penutup tanah $A$. pintoii sudah ada di lapangan, sedangkan tanaman jagung dan kedelai ditanam dengan jarak tanam masing-masing $40 \times 40 \mathrm{~cm}^{2}$.

Pada setiap petak perlakuan dipilih secara acak 10 tanaman sampel yang ditentukan secara sistematis diagonal. Dari setiap sampel diamati dan dikoleksi serangga yang berasosiasi dengan tanaman lada dan tanaman penegak lada sampai batas ketinggian $1,5 \mathrm{~m}$ dari permukaan tanah. Pengamatan yang sama dilakukan pada tanaman tumpangsari (kedelai dan jagung) pada ketinggian maksimal tanaman sesuai dengan pertumbuhannya. Untuk tanaman $A$. pintoï, pengamatan keanekaragaman hayati artropoda digunakan kotak kayu segi empat berukuran $75 \times 75 \mathrm{~cm}$ yang ditempatkan diantara tanaman lada.

Artropoda yang ada pada setiap tanaman contoh, diamati jenisnya, di- hitung jumlahnya, dan dikoleksi. Untuk serangga yang sulit ditangkap digunakan jaring serangga. Pengamatan serangga yang bergerak di permukaan tanah, digunakan jebakan dari wadah plastik diameter permukaan atas $21 \mathrm{~cm}$, tinggi 8,0 $\mathrm{cm}$ dan diisi air $1000 \mathrm{ml}$ yang telah dicampur dengan deterjen. Perangkap ditempatkan pada jarak $30 \mathrm{~cm}$ dari batang tanaman lada, dan dibenamkan ke dalam tanah sampai permukaan atas perangkap sejajar permukaan tanah. Perangkap dipasang 1 hari sebelum pengamatan. Setiap jenis artropoda yang terperangkap diamati jenisnya, dihitung dan dikoleksi. Pengamatan dilakukan setiap 2 minggu sekali, dimulai 2 minggu setelah penanaman jagung dan kedelai sampai kedua tanaman tersebut panen.

Artropoda yang dikoleksi dimasukkan dalam larutan alkohol $70 \%$, selanjutnya disortasi dan diidentifikasi di laboratorium. Identifikasi dengan cara langsung, membandingkan dengan spesimen koleksi, membandingkan dengan gambar, menggunakan kunci identifikasi dan kombinasi dari 2 atau lebih cara identifikasi. Identifikasi dilakukan sampai tingkat famili dan beberapa sampai tingkat jenis.

\section{HASIL DAN PEMBAHASAN}

Dari hasil penelitian, diperolch 44 jenis artropoda yang tersebar pada semua perlakuan ekosistem lada. Status umum dari artropoda tersebut adalah sebagai fitopag $(34,09 \%)$, omnivorus $(6,82 \%)$, musuh alam (predator, parasitoid) $(34,09 \%)$, dan penyerbuk 
$(11,36 \%)$ parasatiod. Jenis hama utama lada yang ada adalah Lophobaris piperis dan Dasynus piperis. Jenis-jenis artropoda tersebut ditemukan di permukaan tanah, pada tanaman lada, tanaman penegak lada, A. pintoii, jagung, kedelai, dan gulma (Tabel 1).

Penyebaran setiap jenis artropoda beragam pada setiap perlakuan yaitu antara 26-34 jenis (Gambar 1), terendah pada pertanaman lada dengan tumpangsari jagung dan tertinggi pada penggunaan A. pintoi dan kontrol. Tinggi-nya jumlah jenis yang ditemukan pada perlakuan $A$. pintoii dan kontrol, tampaknya dipengaruhi oleh kondisi permukaan lahan (tanah) yang tertutup vegetasi baik oleh A. pintoii maupun gulma. Kondisi lingkungan ekologis yang tcrbentuk pada kedua perlakuan tersebut mengundang

Tabel 1. Keanekaragaman artropoda yang berasosiasi dengan ekosistem tanaman lada.

\begin{tabular}{|c|c|c|c|c|c|c|c|c|}
\hline No. & Ordo/Familifienis & LA & LJ & LK & LS & LKn & Status (Umum) & Stadia \\
\hline \multirow[t]{7}{*}{1.} & $\begin{array}{l}\text { Orthoptera : } \\
\text { Acrididae }\end{array}$ & & & & & & & \\
\hline & Acrida turita & + & + & + & + & + & Hama & Imago, nimfa \\
\hline & Valanga nigricornis & + & - & $\cdot$ & - & - & Hama & Imago \\
\hline & $\begin{array}{l}\text { Tetrigidae } \\
\text { Tettigonidae }\end{array}$ & + & + & + & + & + & Hama & Imago, nimfa \\
\hline & Elimaea sp. & + & - & - & - & - & Hama & Imago \\
\hline & $\begin{array}{l}\text { Mecopoda elongata } \\
\text { Gryllidae }\end{array}$ & + & - & - & $\cdot$ & - & Hama & Imago \\
\hline & Grylus mitratus & + & + & + & + & + & Hama & Imago, nimfa \\
\hline 2. & $\begin{array}{c}\text { G. innotabilis } \\
\text { Blattodea (= Blattaria) }\end{array}$ & + & + & + & + & + & Hama & Imago, nimfa \\
\hline & $\begin{array}{l}\text { Blattidae (sp 1-2) } \\
\text { Pycnoscelidae }\end{array}$ & + & + & + & + & + & Omnivorus & Imago, nimfa \\
\hline 3. & $\begin{array}{l}\text { Pycnoscelus sp. } \\
\text { Mantodea } \\
\text { Mantidae }\end{array}$ & + & + & + & + & + & Omnivorus & Imago, nimfa \\
\hline 4. & $\begin{array}{l}\text { Tenodera sp. } \\
\text { Hemiptera }\end{array}$ & $\cdot$ & - & - & + & - & Predator & Imago \\
\hline & $\begin{array}{l}\text { Scutelleridae } \\
\text { Coreidae }\end{array}$ & $\cdot$ & + & + & + & - & Hama & Imago \\
\hline & $\begin{array}{l}\text { Dasynus piperis } \\
\text { Pyrrhocoridae }\end{array}$ & + & + & + & + & + & Hama & Telur, imago \\
\hline 5. & $\begin{array}{l}\text { Dysdercus cingulatus } \\
\text { Lepidoptera }\end{array}$ & - & - & - & $\cdot$ & + & Hama & Imago \\
\hline & Hesperidae & + & - & + & - & + & Penyerbuk & Imago \\
\hline & Saturnidae & - & - & + & - & - & Hama & Larva \\
\hline 6. & Diptera & & & & & & & \\
\hline & Drosophilidae & + & + & + & + & + & Parasitoid & Imago \\
\hline & $\begin{array}{l}\text { Tachinidae } \\
\text { Culicidae }\end{array}$ & - & + & - & $\cdot$ & - & Parasitoid & Imago \\
\hline 7. & $\begin{array}{l}\text { Nyamuk } \\
\text { Coleoptera }\end{array}$ & + & + & + & + & + & & Imago \\
\hline & Coccinellidae (sp, 1) & - & - & + & + & + & Predator & Imago \\
\hline & $\begin{array}{l}\text { Menochlius sexmaculatus } \\
\text { Curculionidae }\end{array}$ & - & $\cdot$ & - & + & - & Hama & Imago \\
\hline & Lophobaris piperis & + & + & + & + & + & Hama & Imago \\
\hline & $\begin{array}{l}\text { L.ophobaris sp. } \\
\text { Cucurniodea }\end{array}$ & + & + & + & + & + & Hama & Imago \\
\hline & Corigetus saturatevirus & + & + & + & + & + & Hama & Imago \\
\hline & Cerambycide & + & - & - & $\cdot$ & - & Hama & Imago \\
\hline & $\begin{array}{l}\text { Chrysomelidae } \\
\text { Melolonthida }\end{array}$ & + & $\cdot$ & - & - & + & Hama & Imago \\
\hline & $\begin{array}{l}\text { Apogonia destructor } \\
\text { Scarabaeidae }\end{array}$ & + & - & - & - & - & Hama & Imago \\
\hline & Chrisocroa fulminaris & - & - & $=$ & + & - & Hama & Imago \\
\hline
\end{tabular}


Tabel 1. Lanjutan.

\begin{tabular}{|c|c|c|c|c|c|c|c|c|}
\hline No. & Ordo/Familijenis & LA & LJ & LK & LS & LKn & Status (Umum) & Stadia \\
\hline \multirow[t]{7}{*}{8.} & Hymenoptera & & & & & & & \\
\hline & Formicidae (sp. 1-6) & + & + & + & + & + & Omnivorus & Imago \\
\hline & Apidae & + & - & - & - & - & Penyerbuk & Imağo \\
\hline & Anthoporidae & - & + & - & + & + & Penyerbuk & Imago \\
\hline & Eumenidae & + & $\cdot$ & + & - & + & Penyerbuk & Imago \\
\hline & Ichneumonidae & - & - & - & + & + & Parasitoid & Imago \\
\hline & Chalcididae & + & - & - & - & + & Parasitoid & Imago \\
\hline \multirow[t]{2}{*}{9.} & Odonata & & & & & & & \\
\hline & Aeshnidae & + & + & + & + & + & Predator & Imago \\
\hline \multirow[t]{2}{*}{10.} & Isoptera & & & & & & & Kasta pekerja \\
\hline & Rayap & $\cdot$ & - & - & $\cdot$ & + & & \\
\hline \multirow[t]{3}{*}{11.} & Araneida & & & & & & & \\
\hline & $\begin{array}{l}\text { Laba-laba (sp 1-2) } \\
\text { Salticidae }\end{array}$ & + & + & + & + & + & Predator & Imago \\
\hline & $\begin{array}{l}\text { Phidippulus sp. } \\
\text { Homoptera }\end{array}$ & + & - & - & - & - & Predator & Imago \\
\hline 12. & $\begin{array}{l}\text { Jassidae } \\
\text { Empoasca sp. }\end{array}$ & + & - & - & + & + & Hama & Hama \\
\hline
\end{tabular}

Keterangan: $\mathrm{LA}=$ lada + penutup tanah $A$. pintoii, $\mathrm{LJ}=$ lada + tumpangsari dengan jagung, $\mathrm{LK}=$ lada + tumpangsari dengan kedelai, LS = lada dengan penyiangan terbatas, $L \mathrm{kn}=\mathrm{kontrol},+=\mathrm{di}-$ ternukan, - = tidak ditemukan.

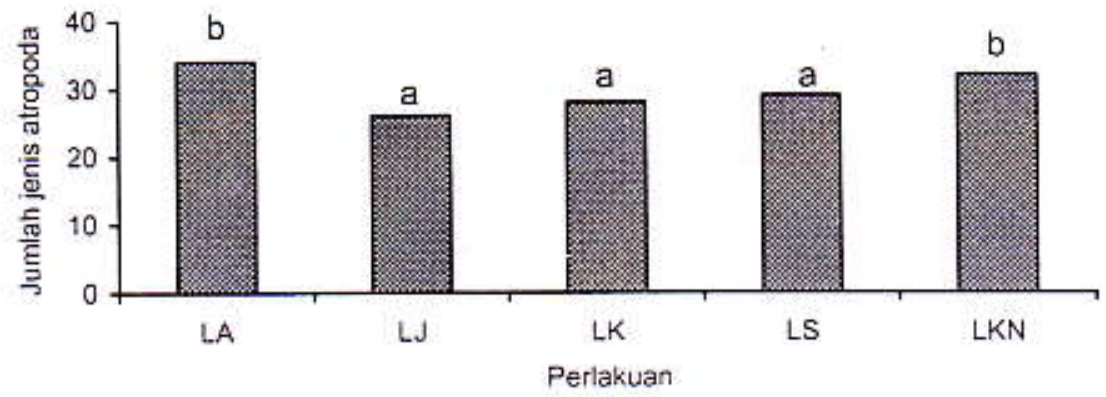

Gambar 1. Sebaran jumlah jenis artropoda pada setiap perlakuan ekosistem lada LA (lada + A. pintoii). LJ (lada + jagung), LK (lada + kedelai) LS (lada penyiangan terbatas), LKn (kontrol).

kehadiran dan menguntungkan artropoda terutama dari kelas insekta (serangga) untuk singgah, menetap dan mencari makan.

Kehadiran jenis artropoda pada setiap pengamatan hampir sclalu sama untuk setiap petlakuan, hanya kelimpahannya yang berfluktuasi terutama pada perlakuan lada dengan jagung dan kedelai. Hal ini kemungkinan berhubungan dengan stadia perkembangan tanaman tumpangsari tersebut. Ordo Isoptera (rayap) hanya ditemukan sekali yaitu pada awal pengamatan, dalam jebakan air pada perlakuan kontrol. Rayap merupakan salah satu hama pada penegak lada. Jenis rayap di Lampung adalah Macrotemtes gilnus (Suprapto, 1989) dan Coptotermes sp. (Bariyah et al., 1992).

Kelimpahan setiap serangga beragam pada setiap perlakuan. Jenis serangga yang populasinya selalu tinggi pada setiap pengamatan adalah ordo Orthoptera (Acrididac, Tetrigidac, dan Gryllidac), Blattodea (Blattidae), Diptera (Drosophilidae), dan Hymenoptera (Formicidae). Anggota dari ordo Orthoptera, Blattodea, dan Diptera umumnya 
ditemukan terperangkap dan bergerak di permukaan tanah, sedangkan anggota Hymenoptera yaitu semut (Formicidae) ditemukan baik di tanah maupun pada tanaman. Semut merupakan scrangga yang populasinya selalu tinggi $>100$ ekor) per pohon. Kelimpahan semut yang tinggi kemungkinan berkaitan dengan sebaran sarang yang ada di sekitar pertanaman, perilaku mencari makan, dan juga pencarian sumber makanan. Kelimpahan total masing-masing artropoda yang terperangkap di tanah dapat dilihat pada Gambar 2.

Di samping famili Formicidae (Hymenoptera), famili dari ordo Orthoptera terutama Gryllidae (jengkerik) banyak dijumpai terjebak dalam perangkap. $\mathrm{Hal}$ ini berhubungan dengan habitat hidupnya di tanah dan di bawah tumpukan serasah, sehingga memungkinkan serangga tersebut terjebak. Jengkerik berdiam diri di dalam tanah dengan membuat lubang atau merusak dan memakan bagian tanaman yang masih muda (Natawigena, 1990). Famili lain dari Orthoptera seperti Acrididae dan Tetrigidae merupakan belalang yang umum ditemukan di rerumputan. Kelimpahannya banyak ditemukan di sekitar tanaman A. pintoii. Menurut Borror et al. (1992) belalang-belalang tersebut adalah pemakan tumbuh-tumbuhan dan sering merusak tanaman.

Berdasarkan kelimpahan total artropoda di tanah (Gambar 3) terlihat bahwa pada kontrol dan perlakuan lada dengan . A. pintoii, jumlahnya paling tinggi dibanding dengan perlakuan lainnya. Kelimpahan total tertinggi pada kedua perlakuan tersebut terutama di-dominasi oleh famili dari ordo Orthoptera yang menyukai ekosistem dengan permukaan lahan tertutup tum-buhan. Di samping itu, kelimpahan juga disebabkan karena banyak anggota dari famili Drosophillidae yang terjebak dalam perangkap.

Pada tanaman lada, terdapat 10 ordo artropoda yang ditemukan. Berdasarkan kelimpahan total masing-masing ordo, Hymenoptera (formicidae) dan Araneida (laba-laba jaring) merupakan yang paling dominan (Tabel 2).

Kehadiran semut (formicidae) pada tanaman lada dan laba-laba jaring

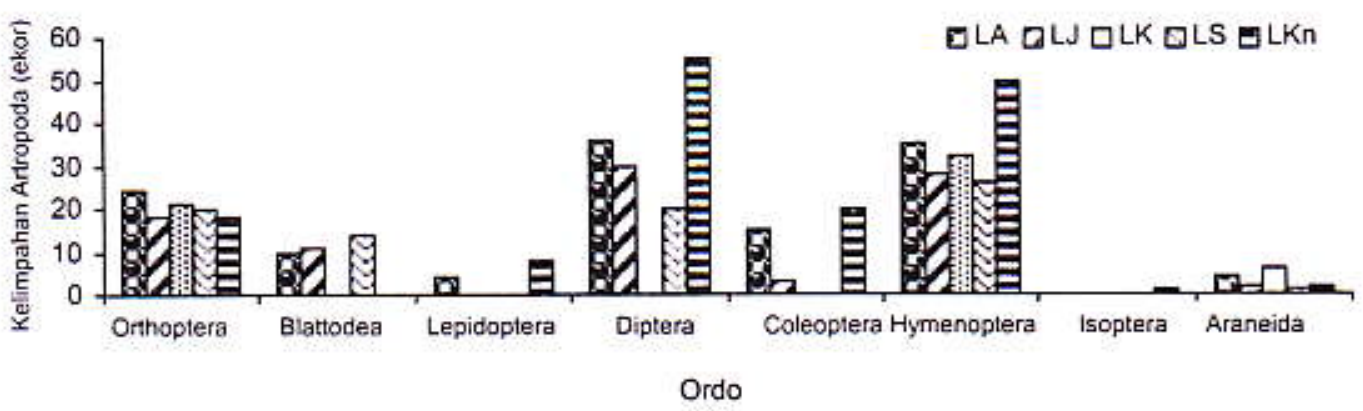

Gambar 2. Kelimpahan Total (ekor) masing-masing ordo artropoda di tanah pada setiap perlakuan ekosistem lada. LA (lada + A, pintoi), LJ (lada + jagung). LK (lada + kedelai) LS (lada penyiangan terbatas), LKn (kontrol). 


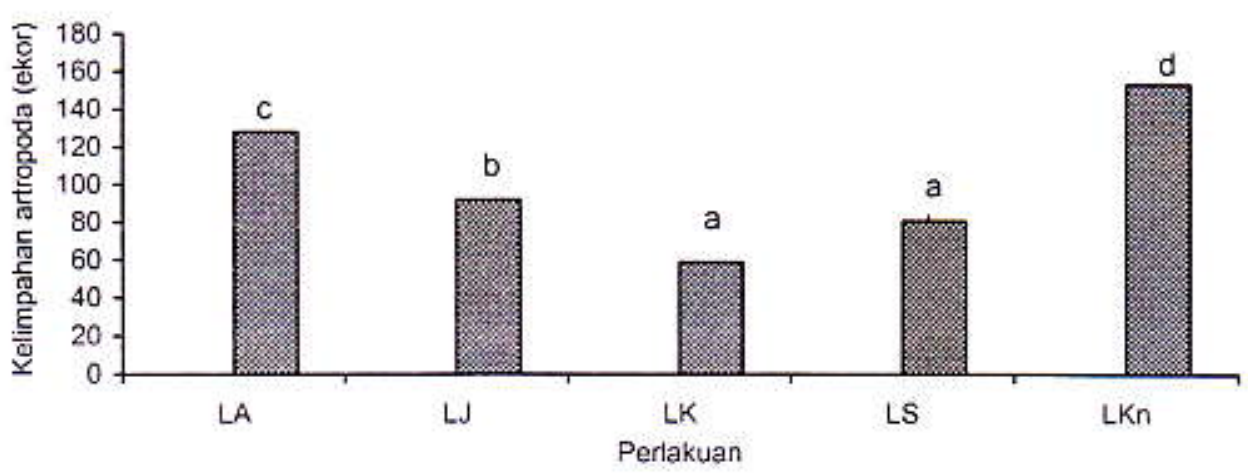

Gambar 3. Kelimpahan Total (ekor) artropoda yang terdapat di tanah pada setiap perlakuan ekosistem lada. LA (lada + A. pintoii) LJ (lada + jagung), LK (lada + kedelai) LS (lada penyiangan terbatas), LKn (kontrol).

Tabel 2. Kelimpahan Total (ekor) artropoda pada tanaman lada pada setiap perlakuan ekosistem lada.

\begin{tabular}{lrrrrr}
\hline \hline Ordo & LA & LJ & LK & LS & LKn \\
\hline Orthoptera & 8 & 2 & 1 & 2 & 2 \\
Lepidoptera & 16 & 2 & 14 & 2 & 4 \\
Diptera & 6 & 2 & 0 & 4 & 16 \\
Coleoptera & 16 & 26 & 12 & 4 & 7 \\
Hymenoptera & - & - & - & - & - \\
Hemiptera & 12 & 6 & 14 & 4 & 10 \\
Mantodea & 0 & 0 & 0 & 1 & 0 \\
Odonata & 0 & 0 & 2 & 0 & 0 \\
Araneida & 196 & 54 & 186 & 218 & 204 \\
Homoptera & 2 & 1 & 0 & 0 & 2 \\
\hline Keterangan: LA (lada + A. pintoi), LJ (lada + jagung). LK (lada + & kedelai) LS (lada penyiangan terbatas). LKn (kontrol). \\
& $-=$ tak terhingga.
\end{tabular}

yang merupakan predator, sangat menguntungkan terutama peranannya yang dapat mengganggu kehadiran hama utama lada. Semut dapat mengganggu kehadiran atau membunuh/memakan baik telur, nimfa, maupun imago hama lada. Menurut Borror et al (1992) semut-semut menghasilkan sekresi eksokrin yang berfungsi dalam penyerangan, pertahanan dan komunikasi. Semut banyak yang bersifac karnivora. Sedangkan peranan laba-laba dalam melindungi buah lada dari serangan hama pernah diobservasi olch Deciyanto et al. (1995) yang menunjukkan bahwa meningkatnya jumlah laba-laba akan diikuti oleh menu- runnya tingkat serangan hama pada buah.

Berdasarkan kelimpahan total (ekor) artropoda pada tanaman lada pada berbagai ekosistem, menunjukkan bahwa pertanaman lada yang dikombinasikan dengan tanaman penutup penutup tanah A. pintoii memiliki jumlah kelimpahan scrangga yang terbanyak dan berbeda dengan perlakuan lainnya (Gambar 4).

Pada tanaman penegak lada, kclimpahan masing-masing artropoda rendah, kecuali dari ordo Hymenoptera yaitu formicidae (semut). Selain semut, hanya Pbidipputus sp. (Salticidae; 
Arancida) dan jenis dari Scutelleridae (Hemiptera) yang ditemukan tetapi tidak tersebar pada semua perlakuan (Iabel 3).

Serangga anggota Scutelleridae adalah pemakan tumbuh-tumbuhan (fitofag) sehingga memiliki potensi untuk berkembang menjadi hama. Monitoring perlu dilakukan untuk memantau perkembangannya. Beberapa jenis hama telah diketahui menyerang berbagai macam penegak lada seperti rayap, Batocera sp., ulat dan kutu daun serta kepik Dysdenzti (Kalshoven, 1981; Suprapto, 1989; Bariyah et al., 1992).

Selain pada tanaman lada dan tanaman penegak lada, beberapa ordo artropoda juga ditemukan pada tanaman A. pintoii, jagung, kedelai, dan gulma (Gambar 5). Ordo Orthoptera terutama belalang mendominasi kehadirannya pada semua tanaman. Kelimpahan serangga dari ordo lainnya yang berasosiasi dengan A. pintoil, jagung, kedelai, dan gulma sangat rendah. Kehadiran Lepidoptera (kupu-kupu) pada tanaman biasanya dalam rangka mencari makanan dan bersifat sebagai penyerbuk atau meletakkan telur, sedangkan serangga dari ordo lainnya di samping mencari makan mungkin juga hanya mencari tempat berteduh, beristirahat atau berlindung.

\section{KESIMPULAN}

Artropoda yang berasosiasi pada ekosistem lada ada 44 jenis, sebagai serangga fitopag, omnirorus, predator, parasitoid, dan penyerbuk. Pola ekosistem lada yang berbeda, menghasilkan sebaran jumlah jenis yang beragam yaitu antara 26-34 jenis, terendah pada pertanaman lada + jagung, sedang tertinggi pada lada + A. pintoii dan kontrol. Pola ekosistem lada berpengaruh juga terhadap kelimpahan total artropoda baik

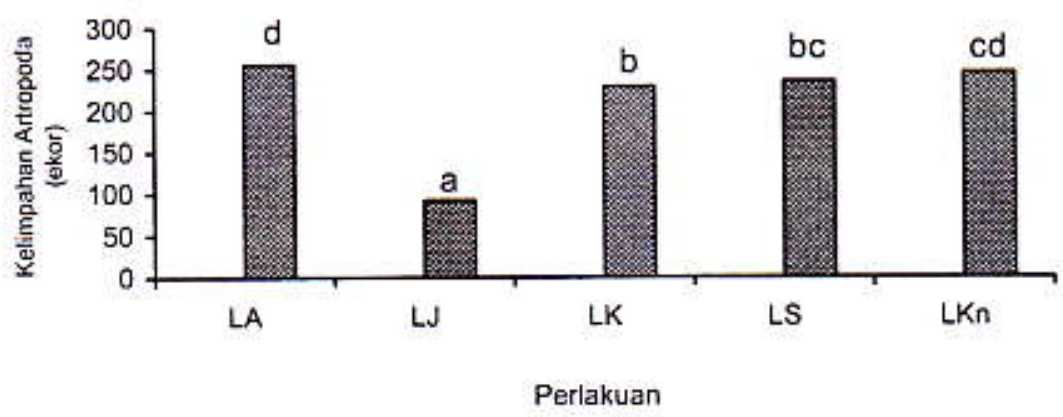

Gambar 4. Kelimpahan Total (ekor) artropoda yang terdapat pada tanaman lada pada setiap perlakuan ekosistem lada. LA (lada + A. pintoii). LJ (lada + jagung). LK (lada + kedelai) LS (lada penyiangan terbatas), LKn (kontrol).

Tabel 3. Kelimpahan total (ekor) ordo artropoda (ekor) pada tanaman penegak lada pada berbagai ekosistem lada.

\begin{tabular}{lccccc}
\hline \hline Ordo & LA & LJ & LK & LS & LKn \\
\hline Hymenoptera (Formicidae) & - & - & - & - & - \\
Araneida (Phidippulus sp.) & 0 & 3 & 0 & 0 & 0 \\
Hemiptera (Scutelleridae) & 0 & 21 & 0 & 3 & 0 \\
\hline
\end{tabular}

Keterangan: LA (lada + A. pintol). LJ (lada + jagung), LK (lada + kedelai) LS (lada penyiangan terbatas), LKn (kontrol). $=$ = tak terhingga. 


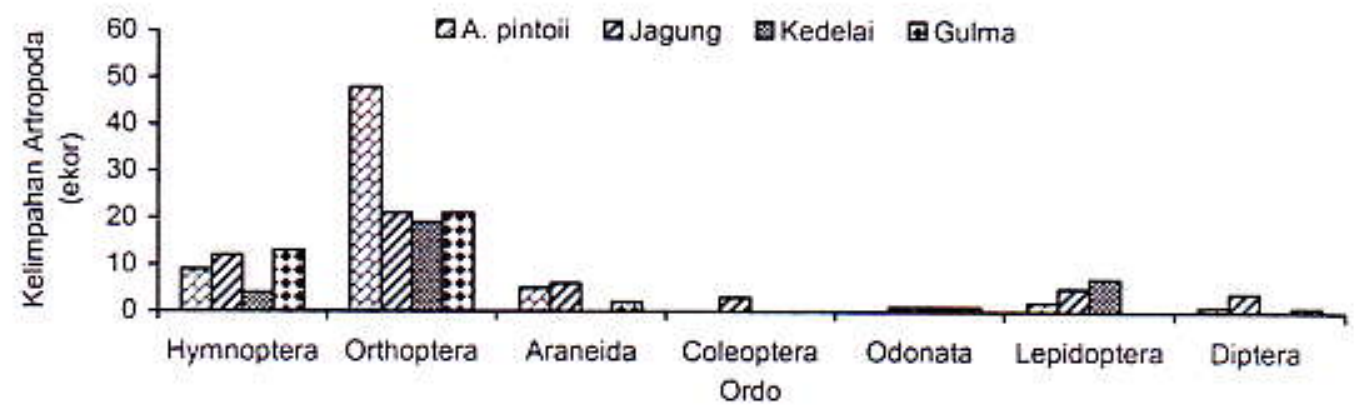

Gambar 5. Kelimpahan Total (ekor) Artropoda yang terdapat pada tanaman A. pintoï, jagung, kedelai, dan gulma.

yang bergerak di permukaan tanah, pada tanaman lada, tiang penegak lada, $A$. pintoii, jagung, kedelai, maupun pada gulma. Struktur tersebut dipengaruhi oleh perilaku dan kondisi ekologis masing-masing perlakuan. Lahan yang tertutup vegetasi lebih disukai oleh serangga terutama dari ordo Orthoptera. Semut (Formicidae) merupakan serangga yang penyebarannya merata dan populasinya selalu tinggi. Kehadirannya dengan laba-laba jaring pada tanaman lada dapat difungsikan untuk mengganggu kchadiran hama.

\section{DAFTAR PUSTAKA}

Bariyah, B., Z. Assawi, dan E. Karmawati. 1992. Observasi Hama Tiang Panjat di Lampung dan Bangka. Mledia Komunikasi Penelirian dan Pengembangan Tanaman Industri. 9:78-80

Borror, D.J., D.M. Delong, dan C.. A. Triplehorn. 1992. Pengenalan Pelajaran Serangga. Diterjemahkan oleh Partosoedjoro, S. Gajah Mada University Press. Yogyakarta.

Chinery, M. 1991. Collins Guide to The Insects of Brimain and Western Europe. Wm. Collins \& Sons Co Ltd.

Deciyanto, S., Wiratno, and Z. Asnawi. 1995. Preliminary Study on The Existance of
Spider Web in Black Pepper and its Role. J. of Spice and Medicinal Crops. 3(2):31. 36

Dhalimi, A., M. Syakir, dan A. Wahyudi. 1996. Pola Tanam Lada. Monograf Tanaman Lada. Balittro. P. $76-84$

Kalshoven, L.G.E. 1981. Pests of Crops in Indonesia. P. I. Ichtiar Baru van Hocve. Jakarta.

Natawigena, H. 1990. Entomologi Pertanian. Orba Sakti. Bandung.

Sastrosiswojo, S. dan I $\mathrm{N}$. Oka. 1997. Implementasi Pengelolaan Serangga secara Berkelanjutan. Prosiding Kongres Perhimpunan Entomologi Indonesia I dan Simposium Entomologi. PEI dan Lniv, Padjadjaran Bandung, p. 47.58.

Sosromarsono, S. 1981. Suatu Tinjauan Pengendalian Hama Tanaman. Majalah Pertanian. Depran. Jakarta. p. 1-6

Suprapto. 1989. Pengaruh Serangan Rayap Macrotermes gilvus Hagen pada Guludan terhadap Tanaman Lada. Bulletin Balittro. $4(2): 87-93$

Suprapto. 2000. Manfaat Penggunaan A. piutoü rerhadap Perkembangan Musuh Alami Organisme Pengganggu Tanaman Lada. Makalah Workshop Nasional Pengendalian Hayati OPl Tanaman Perkebunan 15-17 Pebruari 2000, Bogor. 12 p.

Untung, K. dan M. Sudomo. 1997. Strategi Pengelolaan Serangga secara Berkelanjutan. Prosiding Kongres Perhimpunan Entomologi Indonesia Y dan Simposium Entomologi. PEI dan Univ: Padjadjaran Bandung. p. 36-46 


\title{
Hubungan antara Zea mays L., Ostrinia furnacalis (Lep.: Pyralidae) dan Beauveria bassiana Vuill.
}

\author{
ITJI DIANA DAUD \\ Jurusan HPT, Fakultas Pertanian Universitas Hasanudin \\ J1. Perintis Kemerdekaan Km. 10 Makasar \\ (diterima Oktober 2004, disetujui April 2005)
}

\begin{abstract}
Connection between Zea Mays L., Ostriana furnacalis (Lep.: Pyralidae) and Beauveria bassiana Vuill. The entomopatogen fungus, Beannsia bassiana (Balsamo), is obtained in the tissuc of corn plant through submersion of seed in cinidia $10^{\mathrm{ti}} / \mathrm{ml}$. Tissue observation showed that hifa $B$. bassiana appears when the plant attain the age of threc wecks and when it reaches six wecks B. bassianta appears in all sample plants. Hifa obtained in parenchyma rissue passively without causing illness to the mother plant. The appearance of $B$. bassiana is remained until the $12^{\text {th }}$ weeks of the plant. Bio test of plant which contain the endofit of $B$. bassiana showed the percentage of tested insect mortality is $64 \%$. The observation showed that the corn plant can still produce the toxin of beauverisin.
\end{abstract}

KEY WORDS: Beauveria bassiana, Ostrinia furnacalis, Zea mass. Endofit, Beasuerisin.

\section{PENDAHULUAN}

Cendawan Beauneria bassiana merupakan cendawan entomopatogen, efektif untuk mengendalikan serangga Darna iatenata (Daud, 1995), Helivonepha armigera (Daud et al., 1997), Captotermes spp. (Tikupadang dan Saranga, 1999) serta Ostrinia furnacalis (Soenartiningsih, 1996; Daud dan Besse, 1998).

Keefektifan B. bassiana dalam mengendalikan $O$. furnacalis di lapang memberikan satu kemungkinan bahwa cendawan ini bersifat endofit, karena niche $O$. furnacalis berbeda dengan hama lainnya seperti yang disebut diatas yaitu hidup dalam batang dengan meng-gerek jaringan batang jagung. Dalam hal ini cendawan berpenetrasi pada akar tanam- an dan ditranslokasikan secara sistematik ke seluruh jaringan tanaman.

\section{BAHAN DAN METODE}

Bahan Cendawan Beameria basiama diperoleh dari koleksi Itji Diana Daud yang berasal dari Ostrinia furnacalis. Cendawan ini dikulturkan pada medium jagung giling dalam botol dengan diameter $6 \mathrm{~cm}$ dan tinggi $11 \mathrm{~cm}$ sclama 2 minggu. Spora cendewan untuk perlakuan benih diperoleh dengan cara menambahkan akuades pada kultur cendawan dan kemudian disentrifugasi. Suspensi spora diambil dan diteteskan pada Haemotesimeter untuk penghitungan. 


\section{Bahan Tanaman}

Benih jagung varietas semar direndam dalam suspensi spora $10 \mathrm{H} / \mathrm{ml}$ selama 24 jam. Benih ini ditanam dalam polibag yang diisi $10 \mathrm{~kg}$ campuran tanah, pasir dan pupuk kandang yang telah distelirisasi. Setelah tanaman berumur 1 minggu daun, batang dan akar diambil untuk diamati keberadaan B. bassiana

\section{Metode Pelaksanaan :}

1. Metode deteksi keberadaan $B$. bassiana pada jaringan tanaman (Tabel $1)$.

2. $\mathrm{Lji}$ Bio

Untuk mengetahui pengaruh $B$. bassiana yang berada dalam jaringan tanaman terhadap monokotil larva $O$ furnacalis maka dilakukan uji bio

Uji bio ini dilakukan dengan menggunakan varietas semar sebanyak 5 tanaman dinfertasi dengan larva sebanyak 5 ekor, lalu tanaman di sungkup selanjutnya dilakukan pengamatan terhadap banyaknya larva yang mati.

Rumus perhitungan mortalitas

$$
\begin{aligned}
& \mathrm{P}=\frac{\mathrm{T}-\mathrm{H}}{\mathrm{T}} \times 100 \% \\
& \mathrm{~T}=\text { Jumlah Larva yang diuji } \\
& \mathrm{H}=\text { Jumlah larva yang hidup } \\
& \mathrm{P}=\text { Jumlah larva yang mati }
\end{aligned}
$$

3. Pengamatan Toksin dengan kromatograf TLC untuk mengetahui senya- wa yang dihasilkan seperti beauverisin selama B. bassiana berada dalam jaringan akar, daun dan batang jagung, ekstraksi jaringan tanaman yang mengandung B. basiama, larutan beauverisin, ektraksi jaringan tanaman tanpa B. bassiana dan ektraksi miselium B. bassiana, dilakukan revelasi pada plat kromatografi dan revelasi tersebut dilakukan dengan perendaman plat kromatografi pada larutan kloroform ditambah etil asetat dalam tabung revelasi.

Hasil revelasi diuji secara biologis dengan menyemprot suspensi Gliocladium sp. Inkubasi dilakukan sclama 7 hari. Nilai Rf dihitung menggunakan rumus:

$$
\begin{aligned}
\mathrm{Rf}= & \frac{\mathrm{x}-\mathrm{xi}}{\mathrm{x}} \\
\mathrm{x}= & \text { jarak yang ditempuh oleh larut- } \\
& \text { an pembawa dari titik start } \\
& \text { hingga titik akhir. } \\
\mathrm{xi}= & \text { Jarak antara titik star dengan } \mathrm{f} \\
& \text { reaksi penghambatan yang ter- } \\
& \text { bentuk. } \\
\mathrm{Rf}= & \text { Revelasi dari berat molekul } \\
& \text { yang terbentuk }
\end{aligned}
$$

\section{HASIL DAN PEMBAHASAN}

B. bassiana yang berada dalam suspensi konidia dengan konsentrasi $10^{\mathrm{H}} / \mathrm{ml}$ dapat beradhesi pada permukaan benih jagung, berkecambah dan berpenetrasi pada permukaan serta tumbuh

Tabel 1. Metode deteksi keberadaan B. bassiana pada jaringan tanaman,

\begin{tabular}{lll}
\hline \hline Metode & Bagian Tanaman & Pustaka \\
\hline Pewarnaan & Batang dan biji & White et. al., 1993 \\
Fiksasi & Biji & White et al., 1993 \\
Pewarnaan & Daun dan akar & Keogh et al., 1980 \\
\hline
\end{tabular}

